\title{
СВЕТИОТ ПРОСТОР И СВЕТОТО ВРЕМЕ ВО ТЕОРИЈАТА ЗА РЕЛИГИЈАТА НА МИРЧА ЕЛИЈАДЕ
}

\section{Кратка содржина}

Во текстот се прикажани категориите на просторот и на времето преку дихотомијата свето-профано и преку карактеристиките на верувањето на религиозниот човек во светото во теоријата на Мирча Елијаде. Светиот простор е поважен од профаниот, тој е хетероген, влегувањето во него подразбира влегување во подрачје со специфичен и супериорен онтолошки статус. Сместувањето во светот за примордијалниот и за современиот верник е преку ориентирање со помош на светото како иентар, како оска (оттука и верувањата во „оската на светот“ и во симболиката на цеентарот), обезбедувач на безбедна средина, создавач на космос. Митовите како свети сказни раскажуваат за космогонијата, која подразбира топогонија, а со нивната светост и перформативни моќи имаат способност да ја реактуализираат состојбата на иниџијалното излевање на светото, на дејствувањето на светите предии или божествата. Tа$\kappa a$, понатамоино сместување подразбира мимезис на иницијалното диференцирање и структурирање на елементите на светот. Реактуализирањето на космогонијата, покрај подражавање на топогонијата, подразбира и навраќање во светото време на Почетокот. Светото време е исто така нехомогено, и религиското повикување на светоста од „она време“ (како што го нарекува Елијаде) значи прекин на профаното траење и воведување на време кое не поминува, но кое има способност да ја обновува стварноста на верникот во култот.

Клучни зборови: СВЕТО, ПРОСТОР, ВРЕМЕ, СМЕСТУВАҢЕ, ПОЧЕТОК, ОСКА, ЦЕНТАР

\section{Светото постоење на религиозниот човек}

Едно од основните верувања на религиозниот човек во статусот и моќта на светото, или можеби најосновното и најсуштинско верување, е дека светото е спротивставено на профаното, не во смисла на тоа дека се наоѓa спроти него на иста линија, како спротивставен пол, појава, концепт, туку во смисла на тоа дека се наоѓ⿱ отаде него, дека е поважно од него, онтолошки и аксиолошки супериорно, перформативно, уредувачко. Оваа свето-профано дихотомија, ${ }^{1}$ подразбира де-

\footnotetext{
${ }^{1}$ Хетерогеноста меѓу светото и профаното не е налик ниедна друга. Така, според Емил Диркем (Émile Durkheim) „... во историјата на човековата мисла нема друг пример на две категории кои се толку длабински диференцирани и толку радикално спротивставени една на друга“ (É. Durkheim, Les formes élémentaires de la vie religieuse, Paris, PUF, 1968, p. 68).
} 
ка тие имаат сложен однос, затоа што иако навидум неповрзани, целата поента и функционирање на религиозното верување произлегуваат од нивната врска, односно двојна спрега. Така, додека е точно дека се верува дека светото и профаното припаѓаат на две сфери без ништо заедничко, точно е и дека тие сфери доаѓаат во контакт во рамките на практикувањето на религијата, организирано, планирано и контролирано во рамките на верувањата и практиките на култот, кои варираат во различни култури и периоди, еволуирајќи и трансформирајќи се, но задржувајќи ја опозицијата и потребата за поврзување на профаното со светото, и на моќта на светото врз профаното. Определувајќи го светото како нешто извонредно, според теоријата на Рудолф Ото (Rudolf Otto) за нуминозното (светото) како „нешто сосема друго“ (ganz andere), сосема инакво од вообичаената сфера на профаниот, секојдневен, познат и близок свет, Мирча Елијаде (Mircea Eliade) ${ }^{2}$ смета дека тоа се

Светото и профаното не можат да бидат споредени со традиционалната опозиција меѓу доброто и злото, затоа што тие припаѓаат на ист род и се во подрачјето на моралот, како што здравјето и болеста се само два различни аспекта на истиот род на факти на животот. Светото и профаното секогаш и секаде се доживуваат и разбираат како различни родови, како два света кои немаат ништо заедничко. Енергијата и моќта во едниот свет (светиот) не само што не се како оние во другиот (профаниот), туку се различни по квалитет, на повисоко ниво.

${ }^{2}$ Во своето дело Светото и профаното (Le sacré et le profane, Paris, Gallimard, 1965, прв пат издадено како "Das Heilige und das Profane" во Rowohlts Deutsche Enzyklopaedie, Ernesto Grassi, ed.), Елијаде најавува дека има намера да го анализира светото in toto, но веднаш потоа ја повторува основната дихотомија на Диркем. Сепак, тоа го прави без во оваа инстанца да се повика на него, иако со неговата теорија има многу повеќе поклопувања отколку со онаа на Ото од неговото дело Cветото (Das Heilige) (со кого се согласуваат околу амбивалентната природа на светото, но не и на планот на развојот на религиските чувства и дејства). Елијаде реферира на Диркем во La nostalgie des origines (за прв пат издадена како The Quest, Chicago, 1969). За Диркем религијата е проекција на социјалното искуство, резимира Елијде, и после дискусија со критичарите на Диркем кои сметаат дека теоријата за тотемизмот нема покритие во заедници во кои нема (верување во) тотеми, заклучува дека Елементарните форми на религиозниот живот останува многу влијателно дело (M. Eliade, La nostalgie des origines, Paris, Gallimard, 1979, pp. 37-38). Очигледно е дека Елијаде го зема концептот на Ото за светото како нешто сосема друго и како амбивалентен концепт, но уште поочигледен е неговиот третман на светото во опозиција со профаното. Идејата за дијалектиката на светото и профаното понатаму ја развива Томас Џ. Џ. Алтајсер (Thomas J. J. Altizer) во првата книга посветена на делото на Елијаде, Mircea Eliade and the Dialectic of the Sacred, издадена во 1963.

Брајан C. Рени (Bryan S. Rennie) се согласува со тоа дека е сосема очигледна сличноста со Диркем, поради развојот на поимот низ дијалектиката свето/профано (B. S. Rennie, Reconstructing Eliade: Making Sense of Religion, New York, State Univeristy of New York Press, 1996, p. 27). Рени исто така смета дека влијанието на Диркем врз Елијаде е поголемо од она на Ото (B. S. Rennie, op. cit., 172). Џон Д. Дадоски (John D. Dadosky) не се согласува со ова, сметајќ дека додека е „... невозможно да се определи колку Елијаде должи на обајцата, барем има доволно докази, како и доволно согласување меѓу истражувачите дека Светото имало значајно влијание врз концептот на Елијаде за светото“, смета тој (J. D. Dadosky, The Structure of Religious Knowing - Encountering the Sacred in Eliade and Lonergan, New York, 
пројавува низ просторот и времето преку хиерофании кои се секогаш кратофании, затоа што, колку и да е светото сконцентрирано во мало место или ситен објект, краткотрајно и минливо, тоа е секогаш екстериоризација на отадеземска, надвообичаена сила или моќ. Чувствувањето на светото како пројавено во просторот и времето се карактеризира со серија дихотомии произлезени од иницијалната дихотомија на две сфери со различен степен на онтолошка важност. Архаичното разбирање на просторот и времето се разликува од модерното: со тоа што архаичниот човек е по дефиниција религиозен, категориите за него се во религиски рамки, а според тоа и сфаќањето на неговото постоење и дејствување во стварноста што ја искусува и стварноста што ја концептуализира. Ваквото разбирање, колку и Елијаде да инсистира во својот опус на важноста на светото за примордијалниот верник, не е ограничено само на архаичните заедници: зачуваното, одржано свето во модерноста, барем во рамки на просторно-временското важење, тоа функционира на мошне сличен начин како и во минатото, независно дали се верува (како Ото), во еволуција на светото и рафинирање на начините на верување, или пак (како Елијаде) во иницијална совршена состојба и опаѓање и губење на основната светост од Почетокот. Покрај тоа, феноменологијата на светото подразбира и серија преклопувања на просторот и времето како онтолошки категории во верувањето на религиозниот човек. Така, додека екстериоризацијата на светото низ нешто (а тоа може да се пројави низ било што, што не значи дека се пројавува низ сѐ) во просторот не мора да биде регулирана во рамки на определено свето време, сепак перцепцијата на таа светост и содејството со неа, со тоа што се надвор од сферата на профаното, припаѓаат на време кое е надвор од обичното, различно од него. За религиозниот човек има два начина на постоење како бивање-во-светот, според Елијаде, свет и профан, и обата се разбираат преку искусувањето и ориентирањето во рамките на просторот и времето.

Просторот е хетероген - кога верникот го напушта подрачјето на профаното и влегува во подрачјето на светото, тој не го менува само местото каде се наоѓa, туку и сопствениот идентитет, дел од светоста се пренесува на него, затоа што контагиозноста и тенденцијата за пролиферација се едни од главните карактеристики на светото. ${ }^{3}$ Светото време, пак, подразбира нужно излегување од трае-

State University of New York Press, 2004, pp. 21-22). Ова важи доколку под „докази“ се подразбира споменувањето на Ото од страна на Елијаде и неспоменувањето на Диркем во било кој контекст супстанцијално поврзан со теоријата за светото.

${ }^{3}$ Светото и профаното имаат јаз меѓу нив, но парадоксот е што токму јазот им ја овозможува меѓусебната врска. Верникот надвор од храмот е инаков од верникот навлезен во светото место. Така, прагот на градбата е местото кое истовремено ја покажува разликата меѓу двата начина на постоење - светиот и профаниот, а истовремено и местото преку кое тие комуницираат. Покрај практичната профана вредност, која ја задржува до денес, прагот во голем број култури има специфично значење. Се верува дека суштествата кои се чувари на објектот се лоцирани на прагот, затоа таму се принесуваат жртви или се прават мини-ритуали на премин од еден простор во друг. Светилиштата се врати или прагови кон божествата, ја претставуваат врската меѓу природниот и натприродниот свет (односно земјата и небото). Од опсежната литература, во E. J. Wilson, "Holiness" and "Purity" in Mesopotamia, Ne- 
њето на мерливото време на секојдневниот живот, создавање на време кое, всушност, и не е време, а е единственото време кое вреди, квалитативно време, наспроти профаното, „квантитативно“. ${ }^{4}$ Светото време се воведува со тоа што се повикува во профаното траење за да го укине, и да се наврати на времето од Почетокот на светот, од создавањето, време во кое, според верувањето на архаичниот човек, прв пат се излеало светото и светот бил онтолошки супериорен над оној сегашниот, кој страда од минувањето на времето, а со тоа, и опаѓање на присутноста и моќта на светото во него.

\section{Свето сместување}

Светото е во основата на религискиот феномен и на почетокот на светот со тоа што светото е од времето на Почетокот, односно основното започнување на времето, и во создавањето на (деловите на) светот, кога тоа се реактуализира во современите околности за верникот, тоа има моќ да ги оживее карактеристиките на тој Почеток. Митовите се свети сказни кои раскажуваат за создавањето на светот. Според Елијаде, сите митови, всушност, раскажуваат за космогонијата. Митовите раскажуваат за преминот од хаос (бездна, празнина), од непостоење или нејасно и неиздиференцирано постоење, кон космос, безбедна уредена средина во која може да се ориентира, а потоа и за начините, појавите и односите во таквиот свет, на тој начин регулирајќи го човековото оденсување во заедниците и одредувајќ́ го неговиот идентитет. Значи, може да се каже дека создавањето на светот подразбира создавање простор. За светот да постои, мора да постои простор во кој би биле сместени неговите елементи, односно, може да се каже дека составните компоненти на светот зависат од местата за да можат да се најдат некаде и да почнат да бидат. ${ }^{5}$

ukirchen-Vluyn, Verlag Butzon \& Bercker Kevelaer, 1994, p. 13; S. Guettel Cole, Landscapes, Gender and Ritual Space - the Ancient Greek Experience, Berkeley, University of California Press, 2004, pp. 178, 181, 184).

${ }^{4}$ Би можело (независно од Елијаде, кој не го споменува тоа), да се направи дистинкцијата меѓу античките концепции за chronos (како траење, дел од сферата на профаното) и kairos (како „квалитативно“ време на соодветност за случување на дејства, еден вид на поклопеност на настани, определена полнотија со значење за одвивање на дејства, настани или појави, или, во контекст на теориите за религијата, литургиско време, време на светоста).

${ }^{5}$ Во оваа смисла во антиката Архита од Тарент тврди дека за воопшто да се биде, треба да се биде во (некое) место. Нештата не можат да постојат независно од местото - ако некој патува до претпоставениот „раб' на вселената, и таму ги рашири рацете, само една рака ќе продолжи да постои. Со тоа што ова се чини апсурдно, Архита заклучува дека премисата за работ на просторот е погрешна, што значи дека вселената мора да е неограничена (С. А. Huffman, Archytas of Tarentum - Pythagorean, Philosopher and Mathematician King. Cambridge, Cambridge University Press, 2005, p. 22). Едуард Кејси (Edward Саsеу) смета дека со мало засилување на тврдењето во аксиомата на Архита, може да се тврди дека ако нештата во светот се веќе во некакво постоење, тогаш тие мора да имаат место за тоа постоење. Затоа, според него светот е свет на места (E. S. Casey, The Fate of Place - a Philosophical History, Berkeley-Los Angeles-London, University of California Press, 1998, p. 4). Во верувањата во 
Хетерогеноста на просторот за религиозниот човек значи дека светиот простор е силен, значаен простор, а профаниот простор е без структура и конзистентност, аморфен. ${ }^{6}$ Според Елијаде, се работи за дихотомија меѓу свет простор, кој е единствениот реално постоечки; и сиот друг простор кој го опкружува. Поделеноста во просторот прави светот да биде создаден, централната оска е референтна точка за секакво натамошно ориентирање. Ваквото религиозно искуство на позиционирање тој го поставува како примордијално искуство кое ѝ претходи на рефлексијата за светот како уреден, за да биде познат, близок и безбеден, што оската го овозможува. Манифестацијата на светото онтолошки го фундира светот, ${ }^{7}$ а првата манифестација е во сместувањето. За религиозниот човек ништо не може да почне без претходна ориентација, ништо не може да биде без фиксен центар. Светото пројавено просторно ја одделува таа територија од околната космичка средина и ја прави квалитативно различна. ${ }^{8}$ Според идејата за оска на светот во сферата на онтолошки супериорното свето, во профаното постоење не е можна вистинска ориентација, затоа што таму нема фиксна точка со таков статус, нема дури ни свет, туку само „... фрагменти на скршена вселена, аморфна маса која се состои од бесконечен број на помалку или повеќе неутрални места ...“.9. Начините на ориентација на религиозниот човек се всушност начини на конструкција на свет простор како репродукција на работата на божествата или светите предци од

кои нема повикување на создател или нема определена точка на создавање, во кои светот отсекогаш постои, навидум не може да се открие важноста на топогонијата во космогонијата, затоа што нема космогонија. Токму во оваа смисла на несоздаденоста на светот се гледа јачината на тврдењето на Кејси: во отсуство на точка на создавање или на Создател(и), може да се тврди дека улогата на одржување на нештата во постоење ја имаат местата во кои тие се наоѓаат.

${ }^{6}$ Ова не значи дека е потполно неиздиференциран, затоа што тоа би значело дека не е космос, туку хаос, а профаниот простор е сепак уреден, и тоа според примерот на светиот. Иако светото е нешто сосема друго во однос на профаното, не значи дека профаното, со тоа што е секојдневно, познато и блиско, е космос, а светото, пак, хаос, ниту обратното - светото е вид на парадигма за профаното, тоа не значи дека неосветеното профано е хаотично, туку значи дека е инфериорно во однос на светото, од него зависно, но и одговорно за контакт со него и негово реактуализирање и одржување.

Според Џ. 3. Смит (J. Z. Smith) хаосот не е само профан, туку е свет „на погрешен начин“. Тој смета дека хаосот е профан, но никогаш не е профан во смисла на тоа дека е неутрален. Хаос добива значење само во религиозен поглед на светот. Проблемот е што за Смит, хаосот е и профан и свет, а всушност ни едното ни другото: тој е исто така света моќ, она кое се спротивставува на редот, кое им се заканува на парадигмите и на архетипите, кое е сепак нужно за функционирањето на креативноста на светото конципирано од Елијаде (J. Z. Smith, Map is not Territory, Leiden, Brill, 1978, p. 97).

${ }^{7}$ M. Eliade, Le sacré et le profane, p. 26.

${ }^{8}$ Во профаното искуство просторот е хомоген, нема прекини кои квалитативно ги диференцираат неговите делови. Ова не значи дека треба да се помеша идејата за хомоген и неутрален геометриски простор со начинот на искусување на профаниот простор, затоа што се работи за две различни нивоа на истражување.

${ }^{9}$ M. Eliade, Le sacré et profane, p. 27. 
митовите. ${ }^{10}$ Секое подоцнежно создавање (во случајов, посветување) е, всушност, реактуализација на космогонијата од митовите. ${ }^{11}$ Посветувањето е нужно, како за воспоставување на ориентација и регулирање на однесувањето, така и затоа што преку него се создава безбедна територија (космос), што му се спротивставува на непознатиот и недетерминиран простор наоколу (хаосот). Овој процес, кој Елијаде го нарекува космизачија на непознати територии е секогаш посветување, затоа што да се организира просторот значи да се повторат парадигматските постапки на светите предци или на божествата. Светата оска на светот, axis mundi, типична за мигрирачки заедници кои ја носат со себе за да обезбедува територии за населување, но присутна и во неномадски култури во различни форми, претставува таков центар на светот. ${ }^{2}$ Религиските концепции и неразделно поврзаните кос-

${ }^{10} \mathrm{M}$. Eliade, Trattato di storia delle religioni, trad. Virginia Vacca, Torino, Boringhieri Editore, 1976, par. 143, Sacré et profane, pp. 30-31, 32, pass. Исто така, ниту изборот на местото кое треба да биде осветено не се избира, туку се открива низ различни хиерофании (кратофании).

${ }^{11}$ Идејата во митската мисла е дека човековите активности се секогаш повторување на дејства некогаш изведени од страна на некој кој не бил токму човек. Нивното значење е поврзано со нивниот квалитет на репродукција (мимезис) на примордијалниот чин, односно со повторувањето на митскиот пример. Во делото Mитот за вечното враќање, истражувањето на Елијаде е насочено во откривање на значењето и основните назнаки на архаичната онтологија, преку податоци кои ги дели на: факти кои покажуваат дека за архаичниот човек реалноста е мимезис на небесен архетип; факти кои покажуваат дека реалноста е во корелација со учеството на симболизмот на центарот, односно преку воведување во постоење на населени места и објекти преку нивното сместување во територија означена од Центарот на светот; и ритуалите и профаните чинови кои ја реализираат смислата што им се одредува само затоа што се реактуализација на дејствата прв пат поставени од божествата, Предците и јунаците ab origine (М. Елијаде, Muтот за вечното враќање, прев. Маргарита Маленкова, Скопје, Слово, 2002, стр. 14, pass., Trattato, par. 142-143).

Елијаде ги зема космогониските митови како парадигма за секое следно создавање (значи и како основа за етиолошките митови). Рафаеле Петацони (Raffaele Pettazzoni) го вбројува космогонискиот мит во групата на митови за потеклото, без да прави разлика меѓу создавањето и потекнувањето (R. Pettazzoni, Saggi sulla storia delle religioni e di mitologia, Roma, Edizioni Italiane, 1946, p. 30 et passim), што е критикувано од страна на Елијаде кој смета дека не е во ред така да се третира митот за создавањето, затоа што, во создавањето на стварите и појавите, секоја нова ситуација на нештата подразбира некоја претходна ситуација, која, во крајна линија, е Светот (создавањето на светот како почеток), каде се содржи потенцијата за сите подоцнежни модификации; потеклото и историјата на светот секогаш ѝ претходат на која и да е друга историја. Секако, треба да се прави разлика меѓу потеклото и настанувањето - нешто има потекло затоа што е создадено, потеклото зависи од создавањето (М. Елијаде, Аспекти на митот, прев. Елена Никодиновска, Скопје, Култура, 1992, стр. 48-50). За дискусијата околу значењето на космогониските митови меѓу Елијаде и Петацони накратко кај Роберт Авенс (Robert Avens) во R. Avens, Mircea Eliade's Conception of the Polarity Sacred-Profane in Archaic Religions and Christianity, Doctoral thesis, Fordham University, 1971, pp. 93-97.

12 Така, во седентарните култури, космолошката слика за столб на светот кој го поддржува сето што постои е карактеристична за Индија, стар Рим, Канарските острови, Британска 
молошки слики формираат систем, кого Елијаде го нарекува „систем на светот“, и таквата концепција е, според него, составена од неколку точки: 1 . свето место кое прави прекин во хомогеноста на просторот; 2. овој прекин се симболизира со отворање на премин од еден космички регион во друг (од небото кон земјата и обратно, како и од земјата до подземјето и обратно); 3. комуникацијата со небото се прави преку определени слики/појави кои реферираат на axis mundi (како столб, скала, планина, дрво, вертикална конструкција како пирамида или зигурат); 4. светот се наоѓ околу оваа космичка оска, затоа што оската е центар на познатиот свет. Истиот симболизам на центарот објаснува други серии на космолошки слики и религиозни верувања, ${ }^{13}$ од кои како најважни Елијаде ги истакнува верувањето

Колумбија, Индонезија. Во бројни култури има свети планини, како Меру во Индија, Хараберазаити во Иран, Планината на Земјата во Месопотамија, Геризим во Израел (,папокот на светот“) (М. Eliade, Trattato, par. 143, М. Елијаде, Митот за вечното враќање, стр. 2125. Исто така, и кај V. Turner, On the Edge of the Bush - Anthropology as Experience, Tucson, The University of Arizona Press, 1985, pp. 114-115) Во делото Златната гранка (The Golden Bough) Џејмс Џорџ Фрејзер (James George Frazer) наведува примери на раширеното обожување на дрвјата кое не го поврзува со дрвјата како вертикала, како оска на светот, но сепак, сосема е веројатно дека меѓу двете концепции постои поврзаност. Најстарите светилишта за Германите, на пример, биле природни шуми (J. G. Frazer, The Golden Bough, Electronic version Wordwordth, London, 1890, The Floating Press, 2009, p. 266). Покрај тоа, во разни култури се верува дека душите на мртвите ги анимираат дрвјата, или пак дека божествата повремено живеат во нив (J. G. Frazer, op. cit., p. 277), затоа има комплексна ритуалност посветена на одоброволување на духовите на дрвјата (ор. cit., pp. 282-323). Остатоците на обожување на дрвјата во Европа до денес се забележливи во англо-саксонската традиција на ритуалот на мајско дрво или мајска пречка (May-tree, May-pole), како ритуал за обезбедување на фертилност на сеидбата, како и на локалните луѓе и животни. Елијаде разгледува комплексни видови на растителни хиерофании кои се наоѓаат во симболите (идејата за космичките дрвја) или во метафизичките митови (дрвото на животот, дрвото на познанието) (M. Eliade, Trattato, par. 15; 95-118). Според Елијде и голем број теоретичари, архитектурата на релативно поновите религиски објекти само ја има пренесено и доразвиено космичката симболика присутна како во организирањето на центарот на светот, така и во градбата на примитивните објекти. Ритуалите кои се во врска со храмови, населени места и слично, произлегуваат од примарното искуство на свет простор (M. Eliade, Le sacré et profane, p. 56, М. Елијаде, Митот за вечното враќање, стр. 25-26).

${ }^{13}$ M. Eliade, Trattato, par. 143. Примери наведува во M. Eliade, Images et symboles, Paris, Gallimard, 1953, ch. 1. Смит се прашува дали категоријата на центарот на која Елијаде обрнува значително внимание не била претесно разгледувана во буквални термини на географски симболизам. На Смит му пречи тоа што Елијаде од една страна ја потенцира комплексноста на симболизмот на центарот, а од друга страна се фокусира на хоризонталната, и особено на вертикалната оска (axis mundi) (J. Z. Smith, Map is not Territory, p. 98). Исто така, проблематично е што Елијаде се концентрира само на центарот, заборавајќи ја периферијата, што не е конзистентно со идејата за коинциденција на спротивности карактеристична за теоријата за светото, смета тој (J. Z. Smith, op. cit., p. 99).

Покрај тоа, според Смит, Елијаде „позајмил“ одредени клучни идеи во врска со симболизмот на центарот, како „...космолошката свет-планина каде небото, земјата и подземјето се поврзани, и подражавањето на оваа схема во човековите дејства на градење, во храмовите и 
дека светите места и светилиштата се ситуирани во центарот на светот; фактот дека храмовите се реплики на космичката планина и ја сочинуваат врската меѓу земјата и небото или земјата и подземјето. ${ }^{14}$ Светите места се слика на светот, imago

палатите“ (J. Z. Smith, To take place, Chicago, London, University of Chicago Press, 1992, p. 15) од таканаречената Пан-бабилонска школа која ги развила овие концепти во доцниот XIX век, откако станале достапни бабилонските и акадските текстови (Ibid.; J. Z. Smith, Map is not Territory, p. 293).

${ }^{14}$ M. Eliade, Le sacré et profane, pp. 38-41. Градбите, населените места и територии имаат небески архетипи. Храмот, поддржува Елијаде со примери од иранската и месопотамската култура, како и од Израел, Индија, Исланд и т.н., бил изграден по примерот на небесен прототип. Паралелно со верувањето во небесната парадигма на градбите, верувањето во архитектонски симбол на центарот го формулира во три точки: светата планина (место на контакт на небото и земјата) се издигнува во центарот на светот; секој храм или света вертикала станува центар; со тоа што таа оска на светот е света, светото место на кое се наоѓa е место на контакт меѓу небото, земјата и подземјето (М. Елијаде, Mитот за вечното враќ㇒ъе, стр. 20-26). Центарот е пред сѐ зона на светото, на апсолутната реалност. Космогонијата е точката на премин од неекстериоризирано кон екстериоризирано свето, на премин од хаос во космос. Затоа ритуалите за реактуализацијата на тоа иницијално свето во архитектурата се толку сложени. Така, Елијаде потсетува на двете основни концепции во ова верување: секое создавање е повторување на космогонијата; и сѐ што е некако фундирано е во центарот (М. Елијаде, Mитот за вечното враќање, стр. 27).

Одговорот на прашањето за тоа дали човековата територија е според парадигмата на небесната (како што е несомнено кај Елијаде) е инаков кај истражувачите со различни пристапи, како социолошкиот на француската школа (кај Диркем, на пример), или трифункционалните хипотези на Жорж Димезил (Georges Dumézil). Ова е проблем кој се провлекува низ историјата: додека за св. Августин божествената држава е пример за земната, или за ПсевдоДионисиј Ареопагит небеската хиерархија пример за световната, за Карл Маркс (Karl Marx) е обратно. Смит, врз база на критиката на Елијаде и надоврзувајќи се на некои ставови на Диркем, има своја комбинирана интерпретација за односот на луѓето со просторот. Сметајќи дека Елијаде ја темели „,архаичната онтологија“ на централизирањето на крал-божество карактеристично за „големите космогонии од Евроазија и Мезоамерика“ (J. Z. Smith, 'Introduction to the 2005 edition' In M. Eliade, The Myth of the eternal return: Cosmos and history, Princeton, Oxford, Princeton University Press 2005, p. xiii), сепак не ја потврдува универзалноста на вака разбраната онтологија, затоа што нема даден јасен метод на интерпретација (J. Z. Smith, op. cit., p. хіi). Смит, затоа, ја коригира метамитологијата на разбирањето на светото како доминантно и супстанцијално (иако не и есенщијално) со ситуационо ориентирање или гледиште - не се небесните созданија архетипални за земските, а овие нивни миметички структури, туку обратно, светоста не е резултат не хиерофанија, туку на избор во контекст, резултат на човековиот значаен труд на (п)осветување. Точно е, сепак, дека Елијаде, колку и да се чини така, нема радикална теорија, прифаќа и хетерогеност и контекстзависност затоа што нештата се свети само за религиозниот човек. Но, за Смит е посоодветно да се следи линијата на Диркем на светото во основата на религијата како колективен феномен. Правилата на колективот кај Диркем се правила на верување во светото во рамките на позитивниот и негативниот култ и обратно, верувањето на светото е правило на колективот, потврда на идентитетот на групата и на нејзините членови. Смит, така, определува дека нешто станува значајно, свето, со самото тоа што се наоѓа на некое соодветно место, со тоа што митско-ритуалното внимание се посветува на него на очигледен начин. Во 
mundi (во смисла на свет свет). Какви и да се димензиите на просторот кој на човекот му е познат и во кој се чувствува најдобро ситуиран (куќата, селото, градот, земјата), религиозниот човек секогаш има потреба да постои во организиран свет, во космос. ${ }^{15}$ Центарот е местото во кое просторот се осветува, тој е пре-еминентно реален. Создавањето подразбира (односно воведува) преобилност на реалноста, наплив на светото во светот. Создавањето на светот станува архетип на секоја човечка активност, независно кое е неговото референтно подрачје. ${ }^{16}$ Со тоа што постојат различни типови на космогонии, постојат и различни начини за „хомологизација“ на местото кое се населува со космосот. Елијаде разликува методи на ритуална трансформација на населеното место (територија, објект) во космос (односно на давање на вредност на imago mundi): преку асимилација со космосот со проекција на четирите хоризонти (страните на светот) од една централна точка; или преку симболичка инсталација на axis mundi; или преку повторување, преку ритуал на конструкција, на парадигматските чинови на боговите преку кои светот настанал. ${ }^{17}$

оваа смисла, нештата не се интринсично свети или профани, се работи за ситуациони категории, затоа, светоста е, пред сѐ, категорија на сместување (J. Z. Smith, To Take Place, p. 104).

${ }^{15}$ M. Eliade, Le sacré et profane, p. 44. Оската на светот е нешто сосема друго, кое креира нешто сосема познато и блиско (космосот). Светите планини кои ги гради човекот се истовремено познати и блиски (тој ги има изградено) и нешто сосема различно од него. Елијаде забележува дека дијалектиката на светите простори и на светиот центар се чини контрадикторна. Цел комплекс на митови, симболи и ритуали ја претставува тешкотијата неповредено да се пристапи и навлезе во центарот, а од друга страна, и истовремено, цела серија на митови, симболи и ритуали го покажува тој центар како достапен и близок (M. Eliade, Trattato, par. 145).

${ }^{16}$ Центарот е, значи, пред сѐ зона на светото, на апсолутната реалност. Затоа ритуалите за реактуализацијата на тоа иницијално свето во архитектурата се толку сложени. Така, Елијаде потсетува на двете основни концепции во ова верување: секое создавање е повторување на космогонијата; и сѐ што е некако фундирано е фундирано, всушност, во центарот (М. Елијаде, Mитот за вечното враќање, стр. 27).

${ }^{17}$ M. Eliade, Le sacré et profane, pp. 51-52.

Ким Нот (Kim Knott), во својата „спацијална методологија“ ја анализира локацијата на религијата, преку компаративни увиди од таканаречениот „просторен пресврт“, обидувајќ се да најде пристап кон локацијата на религијата и на светото во модерните оппштества (на пример, во делото The Location of religion), обидувајќи се да покаже дека религиските истражувања можат да добијат многу од информирана анализа на просторот (K. Knott, 'Geography, space and the sacred', in J. R. Hinnels (Ed.), The Routledge companion to the study of religion, Abingdon, Routledge, 2011, p. 488). Спацијалната методологија започнува од фундаменталната улога на телото за нашето искуство и претставување на просторот, особено со знаците на телото впишани во објектот на истражувањето, дискурсите на телото во релација со објектот, и начините на кои телата го задржуваат и репродуцираат таквото искуство (K., Knott, 'From locality to location and back again: A spatial journey in the study of religion, Religion, 39:2, 2009, p. 158, pass). Потоа, потребни се разледувања на физичките, социјалните и менталните димензии. Местата (вклучувајќ ствари и тела) симултано ги обвиткуваат овие три димензии или „полиња“ на просторот, но заедно во себе собираат и други нешта: 


\section{Навраќање кон времето на Почетокот}

Во чинот на лоцирање на себе си во просторот, човекот ја изразува својата носталгија за Потеклото. Оваа носталгија по Рајот (во смисла на свето време), е истовремено желба на човекот постојано и без напор да се наоѓа во срцето на светот, во центарот или изворот на реалноста и светоста, односно на некој начин да ја надмине човековата состојба и да се врати на иницијалната божествена состојба. ${ }^{18}$

тие се збирот на нивните компоненти, релации, интерпретации и претстави. Едно од својствата на просторот е неговата насоченост кон собирање во себе и конфигурирање. Следниот методолошки чекор кој Нот го предлага вклучува изучување на овие својства во однос на избраното место, што, покрај конфигурација, вклучува и дијахрониска екстензија, синхрониски интерповрзаности, и односи на моќта. Екстензијата го пренесува осетот на времето кое тече низ просторот, како и начинот на кој местата во себе содржат траги од минатите времиња. Синхрониските меѓуповрзаности со други места се исто така важни, затоа што секое место одбрано за анализа е поврзано со други, преку движењето на луѓе и стоки, комуникации и идеи. Преку историски нишки, симултани меѓуповрзувања или тешкотиите што се јавуваат, во просторот секогаш се наоѓа моќ (K. Knott, op. cit., 154-8). Сместувањето подразбира наоѓање на соодветно место за живите суштества и социјалните добра, а синтетизирањето на овие со просторот подразбира индивидуални и колективни процеси на перцепција, прифаќање, имагинација и сеќавање, и заедно, овие процеси овозможуваат создавање и ресоздавање на простор што придонесува во конструкцијата и консолидацијата на општествените структури, што е можно доколку овие се утврдени преку институционални правила и извори, смета Мартина Лев (Martina Löw), заедно со концептот дека одделувањето на простор, односно создавањето на простор, се наоѓa во создавањето на атмосфера што ја обликува (индивидуалната и колективна) синтетизирачка перцепција на просторот, и која произлегува од просторниот ред и има потенцијал да биде намерно „наместена“ да предизвикува одредени ефекти и последици (M. Löw, 'The constitution of space: The structuration of spaces through the simultaneity of effect and perception', European Journal of Social Theory 11 (1), 2008, p. 44).

Целта на истражувањето на Кристиен Барт (Christiane Barth) во C. Barth, "'In illo tempore, at the Center of the World": Mircea Eliade and Religious Studies' Concepts of Sacred Time and Space', Historical Social Research / Historische Sozialforschung, Vol. 38, No. 3 (145), 2013, pp. 59-75 е методолошка комбинација на разбирањето на појавата на просторот во рамките на изучувањето на религијата на Елијаде и Смит, Нот и Лев, сметајќи дека со помош на одредени критериуми, социјалното констиутирање на светиот простор може да се проследува преку поделба на поетиката и политиката на светиот простор, со испитување на перспективите на верникот и апстракција на сликите на светиот простор што се пренесуваат преку главните сказни/текстови од религиите. Таа се прашува дали може да се најде митологија на центарот (како кај Елијаде), или пак се работи за свет простор разбран инаку, како и за тоа дали светите книги и други важни текстови даваат хомогена слика за светиот простор. Комбиниран пристап би подразбирал разгледување на прашањето за архитектурното значење на светиот простор, односно на значење поврзано со местото на градбите и нивната (пред)историја (како кај Смит), со истражување на просторниот ред на градбите и концепциите на атмосферата (како кај Нот и Лев), но и други елементи од компаративни истражувања на сфаќњата на светото сместување.

${ }^{18}$ M. Eliade, Trattato, par. 146. 
За религиозниот човек времето не е хомогено, ниту континуирано. Од една страна го има профаното време, вообичаеното временско траење, во кое се одвиваат чинови без религиско значење, а од друга страна постојат интервалите на свето време, време на периодични чествувања и фестивали, прослави и жртвувања (споменатата chronos-kairos разлика). Додека меѓу овие два вида на време постои остар дисконтинуитет, религиските ритуали служат за безбедно да се поминува од вообичаено профано траење кон светото време. Светото време, за разлика од профаното, не е иреверзибилно, туку напротив, постојано се повторува, затоа што и не „поминува“. Светото време е примордијалното митско време кое се пренесува во сегашноста. Религиските прославувања, било кое „литургиско“ време, е всушност реактуализација на свет настан кој се случил во митското минато, во изворот на времето, во она време (illud tempus). ${ }^{19}$ Да се учествува во религиозен настан значи да се излезе од вообичаеното временско траење и да се спои со митското време кое самиот настан го реактуализира. Светото време, значи, е бесконечно повторливо, не поминува, секогаш останува исто со себе, тоа може да се „хомологизира со вечноста““. ${ }^{20}$ Секој периодичен фестивал значи дека учесниците во него се во истото свето време од претходниот фестивал и сите преходни реактуализации, а тоа е и истото време кое било создадено и посветено од божествата на почетокот на светот. Со учеството во светиот религиозен настан се искусува првото појавување на светото време, онака како што било ab origine, illo tempore. ${ }^{21}$

Како што светото место (светилиште, храм или било кое место) е прекин во просторот и воведува нов простор, така и ритуалите кои во него се изведуваат се прекин на профаното временско траење и воведуваат ново, свето време. Во архаичните религии, ова свето време е митско време, примордијално време во кое историското минато не се наоѓa. Тоа е оригинално време, во смисла на тоа дека

19 Фактот што Елијде ги употребува конструкциите illud tempus и in illo tempore (oнa/moa време и во она/mоа време), за Рени јасно ја покажува идиосинкратската употреба на концептот на времето, од каде и доаѓ тензијата во разбирањето на неговата мисла - меѓу идиосинкратичноста кај Елијаде и длабоко впечатените општи употреби на концептот на времето кај читателите постои дискрепанца (B. S. Rennie, op. cit., p. 77). (In) illo tempore е локативот - во тоа време, се сместува во времето. Рени ја споредува и со „пред многу и многу години“ (once upon a time) фразата од сказните, но со мошне поголема светост (B. S. Rennie, op. cit., p. 81).

${ }^{20}$ M. Eliade, Le sacré et profane, p. 64.

${ }^{21}$ M. Eliade, op. cit., pp. 63-65. И во искуствата на нерелигиозниот човек во профаниот свет има прекин и разлика меѓу монотоното време на вообичаена работа и времето на прослави и спектакли, т.е. фестивалското време. И тој живее во варирачки ритми и е свесен за различниот интензитет - кога има интензивни возбудливи искуства на возвишеност, специфични љубовни чувства или уметнички искуства, на пример, ритамот на времето е различен отколку кога се случуваат вообичаени, рутински настани. Сепак, постои есенцијална разлика меѓу него и религиозниот човек, кој искусува временски интервали кои се свети, што значи дека немаат удел во временското траење пред и по нив, затоа што меѓ двете постои хетерогеност. Овој „... трансчовечки квалитет на литургиското време е недостапен за нерелигиозниот човек“ (M. Eliade, op. cit., p. 65). 
наеднаш настанало, без да биде претходено од друго време, затоа што пред појавувањето на реалноста од митот, време воопшто не постоело. ${ }^{22}$

Елијаде дава примери од разни јазици во кои терминот за cвет (космос) се употребува и во смисла на година. Се работи за верување дека светот завршува кога завршува годината. Лексичките сличности ја откриваат врската меѓу светот и космичкото време. Космосот се конципира како единица која се раѓа, се развива и умира на крајот на годината, за со Новата година повторно да се роди. Повторното раѓање е всушност, само раѓање“ (не „повторно раѓање"), затоа што според оваа концепција, со секоја нова година, времето почнува „од почеток“. Елијаде забележува дека оваа интимна врска меѓу космосот и времето е религиска по природа: космосот се „хомологизира“ со космичкото време (Годината), затоа што обете се свети реалности. Покрај тоа, врската меѓу светиот простор и време е видлива и во структурата на светите градби. Со тоа што храмот, светилиштето, светото место, ја претставува сликата на светот, како што беше покажано, опфаќа и временски симболизам. Во многу култури светилиштето го претставува космосот, но и годината. ${ }^{23}$ Подоцнежни истражувања само го потврдлие ова откритие, дека хра-

22 За јудаизмот, времето има почеток и крај, идејата за циклично време се напушта. Додека божествата во архаичните религии се манифестираат во космичкото време, Бог се манифестира во историското иреверзибилно време и новите манифестации во историјата не може да се сведат на некоја претходна манифестација. Божјите постапки се лични интервенции во историјата и ја откриваат својата важност на избраните луѓе. Во оваа смисла историските настани се теофанија, и обратно. Според христијаните времето почнува одново со раѓањето на Исус, затоа што инкарнацијата воспоставува нов статус на човекот во космосот (М. Eliade, Le sacré et le profane, p. 98; М. Елијаде, Аспекти на митот, стр. 176). Разликата мегу ограниченото време и неограниченото циклично време се лоцира и во идејата за повторното враќање на онтолошки супериорниот иницијален период: додека во цикличното време тој бесконечно многу пати се реактуализира, во учењето за ограниченото време, тој се повторува само еднаш и е поврзан со концепцијата за спасот.

Елијаде толку често инсистира на неисторичноста кај примордијалните луѓе и кај религиозниот човек општо (светата „историја“ е мошне поважна од минатото на директните крвни предци, безвременото време поважно од траечкото профано време), што, иако е религиолог и историчар на религиите, според неговиот пристап тој е анти-историчар на религиите. Архаичниот човек имал различна (односно неусилена) свесност за историјата, постојаното навраќање преку цикличноста на времето и потребата да се реактуализира митскиот почеток значат дека профаната историја е секогаш во заден план (со ова оди и бесполезноста во обидите да се вреднува историското време преку историцистичко учење од идеите во $\mathrm{Mu}$ тот за вечното враќање) - за ова повеќе во G. Dudley, 'Mircea Eliade as the "Anti-Historian" of Religions', Journal of the American Academy of Religion, Vol. 44, No. 2, 1976, pp. 345-359, особено рр. 348-353

${ }^{23}$ Со тоа што сите чинови на конструкција на било што се всушност чинови на рекреација на космогонијата, градењето исто така подразбира воведување на ново време. Со изградбата на било каков објект се „отвора“ ново време, се воведува, од една страна неминувачкото време од иницијалната светост, а од друга страна, нова инстанца на тоа време во сегашноста, со нејзино укинување или надминување. Во многу случаи се внимава да се употреби некаков нумерички или статички симболизам за времето, преку претставување на бројот на денови во годината или годишните времиња. Но, но сите случаи има двојна спрега: конст- 
мот (templum) го означува просторниот, а tempus временскиот аспект на движењето на хоризонтот на просторот и на времето. Поентата на сите овие истражувања и заклучоци, резимира Елијаде, е дека за религиозниот човек од архаичните култури, светот годишно се обновува, односно со секоја нова година си ја враќа својата оригинална светост, која ја имал во моментот на создавање, а која постепено ја губи. Светилиштето, светото место, е истовремено и осветен простор par excellence и сликата на светот, го осветува целиот космос и космичкиот живот, кој е замислен во форма на кружен тек, идентификуван со годината. Годината е конципирана и како затворен круг со почеток и крај и како отворена за (повторно) раѓање во формата на нова година. Со секое означување на Нова година, се јавува ново, чисто, свето и некорумпирано време. Ова време се појавува затоа што секоја Нова година светот повторно се создава. Секое создание почнува во времето пред да постои нештото, ни неговото време не постои, затоа што пред да почне да постои космосот, нема ни космичко време. Преку ова може да се објасни зошто генералната концепција на архаичните луѓе е дека секоја креација се случува во Почетокот на времето. Времето протекува со првото појавување на нова категорија на постоење. Новата година е прилика за пурификација, откупување на гревовите и заштита од лоши влијанија. Серијата периодични феномени поврзани со крајот на времето и почетокот на ново време на крајот на годината Елијаде ги дели на две групи: годишно изгонување на гревовите, болестите и духовите; и ритуали кои претходат и следат на Новата година. Елијаде се повикува на Златна гранка на Фрејзер, каде има каталогизација на овие системи на ритуали во овие две групи. ${ }^{24}$ Не се работи само за современата концепција на завршување на еден временски интервал и почнување на друг, туку се работи за укинување на претходната година и претходното време. Времето не се ресоздава, туку се создава, затоа гревовите и грешките, и индивидуалните и на заедницата, се анулираат. ${ }^{25}$ Во разни

рукцијата на местото (во просторот) воведува време, а од друга страна тоа време ја прави можна конструкцијата на местото. Елијаде забележува дека Херман Усенер (Hermann Usener) прв ја направил етимолошката конекција меѓу templum и tempus, преку конщептот за пресек (Schneidung, Kreuzung (H. Usener, Gotternamerij 2nd. ed., Bonn, 1920, 191 ff во М. Eliade, Le sacré et le profane, p. 68).

${ }^{24}$ М. Елијаде, Mитот за вечното враќање, стр. 59. Слична поделба и во M. Eliade, Trattato, par. 152. Елијаде определува дека кај Фрејзер тие се сведуваат на елементите: пости, капење при крштевка или прочистувања, гаснење и ритуално повторно разгорување на огнот, изгонување на духови (жртвениот јарец е вклучен овде, иако таа концепција би можела да припадне во категоријата на чистење од гревови, во зависност од контекстот). Покрај тоа, карактеристични се и симболични битки, процесии со маскирање, ритуални танци, ритуални оргии и слично. Мошне често иницијациите се случуваат во оваа „висока сезона“, затоа што се работи за време силно потопено во светост.

25 Темата на смртта и повторното раѓање во иницијациите, претставена кај архаичните верници како два света или два вида на постоење во светот - свет и профан - се состои од одделување на инцијантот од групата и навраќање на местото и времето на нивните митски предци. Со влегувањето на нови членови и растењето на групата, животот на култот се зголемува, целината брои повеќ членови, но струкурата и схемите на религискиот живот остануваат непроменети. Реферирајќи и на теоријата на Диркем и на теоријата на Елијаде, 
култури се повторува истата идеја - профаното време ги има истоштено човекот, заедницата и космосот, и затоа мора да се уништи за да се реинтегрира митскиот момент на создавање на светот во сегашноста. Ритуалите кои се изведуваат се ритуали за крајот на светот, тоа се ритуали на холокауст (горење на жртви сепаленици), на праќање на жртвениот јарец далеку од заедницата, потопување на симболичен приказ на минатите гревови во вода, социјална конфузија, идеја за растопување на светот во примордијалните води на последниот ден од годината и т.н. Религиозниот човек е постојано свесен дека дел од него е безвременски, затоа што тој во редовни интервали станува современик на космогонијата. ${ }^{26}$ Во идеите за креација преку уништување, создавање на време преку укинување на претходното време, анулирање на простор и создавање на нов простор, идеите за амбивалентноста на божествата и за комплексноста на негативните и позитивните ритуали се забележува до кој степен религиозниот живот е поврзан со помирување на спротивности. Елијаде забележува дека митовите нудат двојно откритие: од една страна, манифестираат поларност произлезена од еден единствен принцип и потреба за помирување во рекреираното „она време“, од друга страна, ја манифестираат concidentia oppositurum во структурата на божественоста (истовремено и сукцесивно малеволентна и беневолентна, креативна и деструктивна, солидарна и пркосечка, физичка и виртуелна) и т.н. ${ }^{27}$ Хетерогеноста на времето, неговата поделба на свето и профано време, не имплицира само „резови“ кои периодично се прават на профаното траење за во него да се вметне светото време, туку имплицираат и еден вид на солидарност, или континуитет на овие вметнувања. Светиот ритуал е „солидарен“ со оние кои му претходеле и оние кои ке се одвиваат во иднина. ${ }^{28}$ Профаното траење, пак, меѓу двете свети прослави, со тоа што не е трансфигури-

Доминик Фарас (Dominic Farace) определува три основни елементи. Прво, митските предци „еруптираат“ во овој свет; местата од кои доаѓаат (свети планини, водни површини, карпи и сл.) го сочинуваат светиот простор за подоцнежни реактуализации на времето на почетокот. Потоа, митските предци или божествата не остануваат на земјата, но не се ни враќаат на местата од каде се имаат појавено, односно, не ретко се специфицира дека се повлекуваат за повторно да бидат „повикани“. Како трет елемент Фарас го наведува тоа што созданието, односно повторното создавање на светот, се постигнува со голем број на митски предци, чиј број не е сигурен, а секој нов член на култот е на некој начин претставен од свет предок (D. Farace, The Sacred-Profane Dichotomy-A Comparative Analysis of its Use in the Work of Emile Durkheim and Mircea Eliade, as Far as Published in English, A doctoral thesis, Rijksuniversiteit, Utrecht, 1982, pp. 103-104).

${ }^{26}$ M. Eliade, Le sacré et le profane, pp. 71-76, М. Елијаде, Митот за вечното враќање, стр. 59-64, M. Eliade, Trattato, par. 153.

${ }^{27}$ M. Eliade, Trattato, par. 159.

${ }^{28}$ M. Eliade, Trattato, par. 148. Прашање е, меѓутоа, дали ова важи и за реактуализација на космогонијата. Времето е вечно и повторливо, но Елијде експлицитно инсистира на анулирањето на сето претходно, изминато време, со прославата на Новата година. Сегашната и минатата Нова година не можат да имаат однос на „солидарност“, кога секоја нова Нова година ја поништува претходната, значи не само што не се работи за однос на солидарност, туку е на вид на исклучителна дисјункција или инкомпатибилност. 
рано од светото време, не може да има било каков континуитет со хиерофаниското време на ритуалот: траењето се одвива паралелно со светото време, а ова ни се открива како континуум кој е, сепак, прекинуван од појавувањето на профани интервали. ${ }^{29}$ Ритуалот не е само повторување на претходен ритуал (кој, исто така, е само повторување на архетип), туку е во континуитет со претходниот ритуал, тој него го продолжува. Со тоа што хиерофаниите кои се повторуваат секоја година формираат „траење“ на света структура, може да се каже дека тие се континуирани едни на други, затоа што за сето време додека траат годините и вековите, тие припаѓаат на едно единствено време.

Сеќавањето на ова извонредно време на космогонијата е толку важно за религиозниот човек затоа што преку него учествува во онтолошки супериорното време во кое божествата ги манифестирале своите најголеми моќи. Illo tempore космогонијата била врвната божествена манифестација на светост, парадигматскиот збир на чинови на екстериоризација на сила, креативност и преобилност. Елијаде ја резимира концепцијата во две точки: прво, преку годишното повторување на космогонијата времето се (ре)генерира, т.е. повторно почнува како свето време, коинцидирајќ со illud tempus на постоење на светот за прв пат; и второ, преку ритуална партиципација во крајот на светот и неговата повторна креација, човекот станува современик на изворот на времето, се враќа повторно во постоење и ги (ре)генерира своите животни сили, моќни колку и во моментот на неговото прво создавање. Периодичноста во религијата значи бесконечна (ре)употреба на митско време кое станува сегашност. Според Елијаде периодичноста, повторувањето и сегашната вечност се трите карактери на религиското време кои го осветлуваат значењето на неговата нехомогеност, во споредба со профаното траење. ${ }^{30}$ Учесниците во овие ритуали на реактуализација го напуштаат историското време, кое се состои од сите профани интра- и интерперсонални настани за кои се верува дека постојат во светото примордијално време, кое е секогаш исто, затоа што припаѓа на вечноста. Фиксацијата на светото, примордијално време, и помалата вредност која му се дава на историското време не значат дека архаичниот религиозен човек е „заглавен“ во минатото: прво, затоа што не се работи токму за минато, а потоа, и затоа што човекот не го одбива прогресот, туку го прифаќа припишувајќ му извонредни, отадеземски, божествени потекло и димензија. Носталгијата по потеклото и постојаниот стремеж да се живее барем блиску до божественото време на почетокот не значат дека религиозниот човек одбива одговорност за вистинско постоење, напротив. Одговорноста која ја има не е само за сопственото постоење, туку за целиот свет. Верувајќи дека без специфичните свети ритуали светот нема да се обнови, дека без раскажувањето на митовите средината во која живее ќе престане да постои и слично; и посветено обезбедувајќи го продолжувањето на светот, тој е одговорен за многу повеќе отколку за сопственото постоење. Целото однесување, сите модалитети на егзистенција на религиозниот човек се објава на верување во постоењето, а неговата партиципација во посто-

${ }^{29}$ M. Eliade, op. cit., par. 148.

${ }^{30}$ M. Eliade, op. cit., par. 149. 
ењето е преку реактуализација на примордијалното постоење за кое тој е одговорен.

Од космологијата до сотериологијата идејата за регенерација е врзана за пристапот во ново време, односно за верата во апсолутен почеток. ${ }^{31}$ Во сите митови и ритуали кои се однесуваат на космичките циклуси очигледна е желбата за тотална регенерација на времето, секој нов циклус почнува на апсолутен начин, затоа што секое минато и секоја „историја“ се дефинитивно укинати преку нивна реинтеграција во хаосот. $^{32}$

Во јудаизмот (а со тоа и јудео-христијанството), Крајот не е цикличен, и светот нема периодично да се обновува, туку Крајот е единствен, како и космогонијата. Времето веќе не е цикличното време од митовите за Вечното враќње, туку линеарно, неповторливо време со кое не се управува. Сета историја води до есхатологијата, на Крајот на светот на луѓето (на живите и на оние кои се одамна мртви) ќе им се суди за нивните дела. Се губи елементот на обновување на неколкумина избрани, или спасување на една заедница, или целиот род, затоа што оние кои ќе бидат избрани, ќе останат да живеат во вечно блаженство. ${ }^{33}$

${ }^{31}$ M. Eliade, Trattato, par. 154.

${ }^{32}$ M. Eliade, op. cit., par. 155. Сепак, постојаното инсистирање на Потеклото кај Елијаде треба да се прифати со резерва. Не може да се тврди дека интересот на архаичните луѓ бил ограничен само на Потеклото. Погрешно би било од тоа што нерелигиозните архаични заедници се сосема ретки, да се изведе заклучокот дека религиозноста е единствена карактеристика на организираниот живот на примордијалните заедници. Доволно е да се погледнат издржани етнографски студии од различни региони за да се види дека не сѐ може да се сведе на фокусирање на Почетокот (на пример, D. Maybury-Lewis, Akive-Shavante Society, Oxford, Clarendon Press, 1967, pp. 284-286; M. Edel, The Chiga of Western Uganda, London, Oxford University Press, 1957, p. 161, W. H. Oswalt, Alaskan Eskimoes, San Francisco, Chandler Publishing, 1967, p. 210). Џ. А. Салиба (J. A. Saliba) смета дека наместо потеклото и космогонијата, интересот на примитивните луѓе е во „вештерството и магијата, духовите и култот кон предците“ (J. A. Saliba, The Concept of "Homo Religiosus" in the Works of Mircea Eliade: an Anthropological Evaluation for Religious Studies (A Dissertation for the Degree Doctor of Philosophy), Catholic University of America, Washington D.C., 1971, p. 207). Елијаде не ги негира овие подрачја на интерес, само им определува заеднички извор. Богатството на неговите теориски истражувања нуди огромен број примери на партикуларни интересирања и достигнувања на архаичните луѓе. Самиот Салиба, негирајќи го интересирањето за Потеклото, го наведува како контра-факт интересирањето за предците. Тој смета дека нема доволно етнографски материјал за подцржување на тврдењата за реактуализација на космогонијата, ниту дека архаичните луѓе живееле во постојана загриженост за небесните тела и природната средина, за што наведува еден етнографски податок од Меланезија, во која религијата не „обрнува внимание на целосната надворешна средина, туку како на нешто кое се зема како дадено. Не е причина за грижа, освен во ретките ситуации во кои се работи за природни катастрофи, како вулкански ерупции“ (Lawrence and Meggitt, (eds). Gods, Ghosts and Men in Melanesia, Oxford University Press, Melbourne, 1961, 12 во Saliba, op. cit., pp. 207-208). Елијаде вообичаено наведува барем по два извора. Точно е дека теоријата на Елијаде е неиздржана во смисла на недостаток на етнографски докази. Такви се, впрочем, сите теории за религијата кои се фокусираат на потеклото на религиските феномени.

${ }^{33}$ М. Елијаде, Аспекти на митот, стр. 77-78. На Салиба му пречи и тоа што се добива впечатокот дека со инсистирањето на цикличноста на времето во архаичните религии (без да 
Носталгијата по вечноста е аналогна на носталгијата по рајот. ${ }^{34}$ На желбата постојано и спонтано да се престојува во свет простор ѝ кореспондира желбата да се живее засекогаш, благодарение на повторувањето на архетипалните дејства во вечноста. Повторувањето на архетипите ја манифестира парадоксалната желба за достигнување на идеална форма (парадигмата, архетипот), во рамките на условите на човековото постоење, да се биде во временско траење, но без неговите ограничувања, без неговата иреверзибилност. Носталгијата по Почетокот и носталгијата по вечноста покажуваат дека човекот се стреми кон конкретен „рај“ (во смисла на онтолошки супериорна состојба) и смета дека тој се постигнува на земјата и во сегашноста. ${ }^{35}$

навлегува во источните учења, затоа што така аргументацијата му станува уште понеиздржана) се покажува човековиот страв од линеарното или историско време. Не може да се заклучи, смета, дека со тоа што доминира цикличното време, линеарното време се сфаќа како состојба која треба да се одбегнува, инаку во општествата со развиена свест за линеарно време би требало да има страв од цикличното време. (J. A. Saliba, op. cit., p. 216). За Салиба, обете претпоставки што му ги припишува на Елијаде, дека цикличното и линеарното време не можат да постојат едно до друго во иста традиција; јудео-христијанската традиција ја следи линеарната концепција, додека архаичните религии ги претпочитаат цикличните димензии на времето, се претерани: линеарната и цикличната концепција се спротивни, но не контрадикторни и инкомпатибилни. Митовите не овозможуваат бегство од линеарното време, туку спојување на линеарното и цикличното, како coincidentia oppositorum. За втората претпоставка инсистира дека историската димензија на времето се наоѓa во други религиски традиции, за кои Исламот е одличен пример (J. A. Saliba, op. cit., pp. 215-217). Не треба инкомпатибилноста на светото и на профаното време да се идентификува со инкомпатибилноста на цикличното и линеарното време. Салиба заборава што критикува: од една страна смета дека нема доволно етнографски податоци да се потврдат ставовите на Елијаде, што значи дека нема ниту доволно за да се потврди неговата критика на Елијаде; од друга страна поентата на Елијаде е дека линеарното време се укинува во рамките на цикличното време, не затоа што се инкомпатибилни, туку затоа што едното бива асимилирано од другото (минатото се анулира со секоја нова реактуализација на космогонијата, но архаичниот човек, или религиозниот човек општо не е несвесен за минувањето на профаното време, само што значењето кое му го придава не е свето). Што се однесува за втората претпоставка, голем број автори би го сместиле Исламот во групата на јудео-христијански традиции, што го прави овој коментар излишен. Ч. Џ. Хуан (С. J. Hwan) го парафразира Салиба кој истакнува (Saliba, op. cit., 52) дека Елијаде има определено три вида на ставови кон митот и времето: игнорантскиот став на човекот кој живее во профано време, односно само во историското време; состојбата меѓу, во која не се заборава нереалноста на профаното (историското) време; и отрфлањето на профаното време и живеењето само во свето време (ставот на јогинот, на пример). И тој забележува дека има разлика меѓу медијацијата меѓу две времиња (животот на архаичниот човек) и мистично спојување со постојано светото време во кое, вистина, се работи за бегство од профаното (С. J. Hwan, Il sacro e l'uomo, Approccio a Mircea Eliade: l'uomo, essere aperto al sacro (pars dissertationis ad lauream Pontificiae facultatis Teresianum), Pontificia Facultatis Theologica Teresiana, Roma, 2005, p. 39).

${ }^{34}$ M. Eliade, Trattato, par. 146, pass.

${ }^{35}$ M. Eliade, op. cit., par. 156. Р. J. Цви Вербловски (R.J. Zwi Werblowsky) се прашува дали вистината не е во тоа дека цикличниот ритам на архаичното искусување на времето е обид 
Светото постоење во просторот и времето е важно, полно со смисла и значење, реално и вистинско за религиозниот човек. Структурирањето на просторот преку препознавањето на хиерофании и сместувањето во светата реалност и навраќањето на светото време од Почетокот на светот се во основата на разбирањето на светото кај Елијаде и бројни теоретичари на религиите, а претставуваат плодно поле за понатамошни истражувања на потеклото и природата на религијата преку пристапи кон религијата во современото живеење, за плуриперспективно сфаќање на човековиот идентитет.

за избегнување на теророт на историјата, а линеарното време обид за храбро соочување со него, туку обратно: во тоа дека линеарното време е „... патетичен обид да се намали теророт на историјата преку гледање на времето како секвенща на значајни и целисходни настани (со или без божествена интервенција)“. Цикличната схема може да биде нешто во кое човекот безбедно се одржува, но исто така може да се смета за тотален недостаток на смисла, магепсан круг на раѓање, копулација и смрт, повторно раѓaње, копулација и смрт ad infinitum (го парафразира T. C. Елиот (T. S. Eliot). На таквата схематска повторливост може да ѝ се спротивстави со хероизам кој се граничи со нихилизам (Ничеански), или да се спаси од неа преку еднонасочноста на историското време ориентирано кон исполнување на цели. Вербловски не сака да биде погрешно разбран и го остава прашањето отворено (R. J. Z. Werblovsky, 'In Nostro Tempore: Mircea Eliade', Religion, 19, 1989, pp. 132). 


\section{Литература}

Altizer, Thomas J. J., Mircea Eliade and the Dialectic of the Sacred, Chicago, University of Chicago Press, 1963.

Avens, R., Mircea Eliade's Conception of the Polarity Sacred-Profane in Archaic Religions and Christianity, Doctoral thesis, Fordham University, 1971.

Barth, C., "'In illo tempore, at the Center of the World": Mircea Eliade and Religious Studies' Concepts of Sacred Time and Space', Historical Social Research / Historische Sozialforschung, Vol. 38, No. 3 (145), 2013, pp. 59-75

Casey, E. S., The Fate of Place - a Philosophical History, Berkeley-Los Angeles-London, University of California Press, 1998.

Dadosky, J. D., The Structure of Religious Knowing - Encountering the Sacred in Eliade and Lonergan, New York, State University of New York Press, 2004.

Dudley, G., 'Mircea Eliade as the "Anti-Historian" of Religions', Journal of the American Academy of Religion, Vol. 44, No. 2, 1976, pp. 345-359.

Durkheim, É., Les formes élémentaires de la vie religieuse, Paris, PUF, 1968.

Eliade, M., Images et symboles, Paris, Gallimard, 1953.

Edel, M. The Chiga of Western Uganda, London, Oxford University Press, 1957.

Eliade, M., Le sacré et le profane, Paris, Gallimard, 1965.

Eliade, M., Trattato di storia delle religioni, trad. Virginia Vacca, Torino, Boringhieri Editore, 1976.

Eliade, M., La nostalgie des origines, Paris, Gallimard, 1979.

Елијаде, М., Аспекти на митот, прев. Елена Никодиновска, Скопје, Култура, 1992.

Елијаде, М. Митот за вечното враќаъе, прев. Маргарита Маленкова, Скопје, Слово, 2002.

Farace, D., The Sacred-Profane Dichotomy-A Comparative Analysis of its Use in the Work of Emile Durkheim and Mircea Eliade, as Far as Published in English, A doctoral thesis, Rijksuniversiteit, Utrecht, 1982.

Frazer, J. G., The Golden Bough, Electronic version Wordwordth, London, 1890, The Floating Press, 2009.

Guettel Cole, S., Landscapes, Gender and Ritual Space - the Ancient Greek Experience, Berkeley, University of California Press, 2004.

Huffman, C. A., Archytas of Tarentum - Pythagorean, Philosopher and Mathematician King. Cambridge, Cambridge University Press, 2005.

Hwan, C. J., Il sacro e l'uomo, Approccio a Mircea Eliade: l'uomo, essere aperto al sacro (pars dissertationis ad lauream Pontificiae facultatis Teresianum), Pontificia Facultatis Theologica Teresiana, Roma, 2005.

Knott, K., The location of religion, Equinox, London, 2005. 
Knott, K., 'From locality to location and back again: A spatial journey in the study of religion, Religion, 39:2, 2009, pp. 154-60.

Knott, K., 'Geography, space and the sacred', in J. R. Hinnels (Ed.), The Routledge companion to the study of religion, Abingdon, Routledge, 2011, pp. 476-91.

Löw, M., 'The constitution of space: The structuration of spaces through the simultaneity of effect and perception', European Journal of Social Theory 11 (1), 2008, pp. 25-49.

Maybury-Lewis, D., Akive-Shavante Society, Oxford, Clarendon Press, 1967.

Oswalt, W. H., Alaskan Eskimoes, San Francisco, Chandler Publishing, 1967.

Pettazzoni, R., Saggi sulla storia delle religioni e di mitologia, Roma, Edizioni Italiane, 1946.

Rennie, B. S., Reconstructing Eliade: Making Sense of Religion, New York, State Univeristy of New York Press, 1996.

Saliba, J. A., The Concept of "Homo Religiosus" in the Works of Mircea Eliade: an Anthropological Evaluation for Religious Studies (A Dissertation for the Degree Doctor of Philosophy), Catholic University of America, Washington D.C., 1971.

Smith, J. Z., Map is not Territory, Leiden, Brill, 1978.

Smith, J. Z., To take place, Chicago, London, University of Chicago Press, 1992.

Smith, J. Z., 'Introduction to the 2005 edition' In M. Eliade, The Myth of the eternal return: Cosmos and history, Princeton, Oxford, Princeton University Press 2005, pp. ix-xxi.

Turner, V., On the Edge of the Bush - Anthropology as Experience, Tucson, The University of Arizona Press, 1985.

Werblovsky, R. J. Z., 'In Nostro Tempore: Mircea Eliade', Religion, 19, 1989, pp. 129136.

Wilson, E. J., "Holiness" and "Purity" in Mesopotamia, Verlag Butzon \& Bercker Kevelaer, Neukirchen-Vluyn, 1994. 
Marija TODOROVSKA

\section{SACRED SPACE AND SACRED TIME IN MIRCEA ELIADE'S THEORY OF RELIGION}

\section{Summary}

The text offers an overview of the categories of space and time through the sacred-profane dichotomy and the characteristics of the belief in the sacred in Mircea Eliade's theory. Sacred space is more important than the profane one, it is heterogeneous entering it entails a temporary inhabiting of a sphere of a superior ontological status. Emplacement in the world for the primordial as well as for the contemporary believer is thanks to the orientation having the sacred as a centre, an axis (hence, the beliefs in the axis of the world and the symbolism of the centre), something that guarantees a safe environment and creates cosmos.

Myths as sacred tales refer to cosmogony which implies topogony, and with their sacredness and performative powers tend to reactualise the condition of the initial exteriorisation of the sacred, of the actions of the sacred ancestors or deities. Therefore, any subsequent emplacement is mimesis of the initial differentiation and structuring of the elements in the world. The reactualisation of cosmogony, apart from this, includes a return to the sacred time of the Beginning. Sacred time is as non-homogenous as space is, and the religious referring to the sacredness of "that time" (as Eliade employs it) means to cease the profane duration and introduce a time which does not pass, and which has the ability to restore the reality of the religious man.

Keywords: SACRED, SPACE, TIME, EMPLACEMENT, BEGINNING, AXIS, CENTRE 